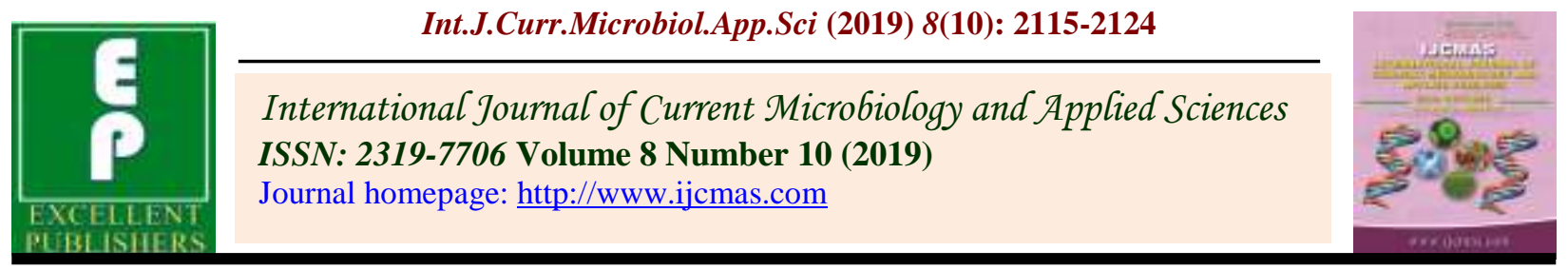

Original Research Article

https://doi.org/10.20546/ijcmas.2019.810.246

\title{
Performance and Cost Economics Evaluation of Different Types of Reaper Binder for Harvesting of Wheat in Satna District of Madhya Pradesh, India
}

\author{
J. Himanshu Rao* and Balveer Singh Meena \\ Department of Engineering and Technology, Mahatma Gandhi Chitrakoot Gramodaya \\ Vishwa Vidyalaya, M.P, India \\ *Corresponding author
}

\section{Keywords}

Binder, Harvesting, Wheat, Agriculture, Labour, Boredom, Crop, Sickle

Article Info

Accepted:

15 September 2019

Available Online:

10 October 2019

\section{A B S T R A C T}

Mechanized agriculture is the process of using agriculture machinery to mechanize the work of agriculture, greatly increasing farm worker's productivity. The use of mechanized power for agriculture purpose reduces not just the hardship faced by the farmers under traditional manual practices but also speeds up agricultural processes, saves cost and enhances agricultural productivity. The present study was undertaken to evaluate the performance of different types of reaper binder operational for harvesting of wheat in Satna district of Madhya Pradesh. The field performance was done by using three different machines. Actual field capacity for machine 1, machine 2 and machine 3 were $0.314 \mathrm{ha} / \mathrm{hr}, 0.222 \mathrm{ha} / \mathrm{hr}$ and $0.295 \mathrm{ha} / \mathrm{hr}$ respectively whereas their theoretical field capacity were $0.3623 \mathrm{ha} / \mathrm{hr}, 0.272 \mathrm{ha} / \mathrm{hr}$ and $0.375 \mathrm{ha} / \mathrm{hr}$ respectively. The field efficiency of machine 1, machine 2 and machine 3 were $86.66 \%, 64 \%, 78.66 \%$, respectively. The labour requirement was $5 \mathrm{man}-\mathrm{hr} / \mathrm{ha}$, $6.77 \mathrm{man}-\mathrm{hr} / \mathrm{ha}$ and $5 \mathrm{man}-\mathrm{hr} / \mathrm{ha}$ for machine 1,2 and 3. The break-even analysis of machine 1 , machine 2 and machine 3 were 32.40 ha/year, 20.47 ha/year and 16.77 ha/year.

\section{Introduction}

India is primarily an agricultural country. Agriculture is the most prominent occupation for most of the Indian families. Over the ages, Indian farmers have mainly used human and animated power and traditional methods passed onto them by their ancestors for cultivation of various agricultural crops. There was not much use of mechanical power in farming practices. These farming practices were time consuming, require huge amounts of human labour, effort and depend heavily on climate and nature.

Advantages of farm mechanization and limitations of agriculture, mechanization of farm operations have become a necessary step 
so as to mitigate the current trend of urbanization by reducing the boredom and drudgery created by farm operations.

Mechanized agriculture is the process of using agriculture machinery to mechanize the work of agriculture, greatly increasing farm worker's productivity. The use of mechanized power for agriculture purpose reduces not just the hardship faced by the farmers under traditional manual practices but also speeds up agricultural processes, saves cost and enhances agricultural productivity.

In most of the developing countries, harvesting operation is usually performed manually using sickle which not only consumes time but also requires labour.

Moreover, timely harvesting may be faced by problems of low work efficiency and adverse climacteric conditions, which cause great loss of cereals (Pandey and Devnani, 1985). In India, harvesting of wheat and rice is still done traditionally by sickle, whereas traditional harvesting is time consuming, costly and laborious. According to Nadeem (1983), traditional harvesting requires almost $25 \%$ of the total labour requirement of the cultivation of any crop. Depending upon the crop yield, 120 to 250 man-hr is required for cutting, bundling and on-field stacking of one hectare of paddy field by using traditional sickle (Nadeem, 1983). It is also reported that the total labour requirement harvesting by sickle is $240 \mathrm{man}-\mathrm{hr} / \mathrm{ha}$ (Mondol, 1997; Shakoor and Salim, 2005).Timely harvest of the crop is vital to achieve better quality and higher yield of the crop. The shortage of labour during harvesting season and vagaries of the weather cause greater losses to the farmer. It is, therefore, essential to adopt the mechanical methods so that the timeliness in harvesting operation could be ensured and field losses are minimized to increase the productivity and production in the farm.
Mechanized harvesting operations have made combine harvester prevalent in many segments of the country for harvesting due to its advantage of harvesting and threshing simultaneously. A combine harvester enables harvesting of grains from an area of 2 hectares in 1 hour (Byszewski, 1977). But there are certain limitations of using combined harvester such as its high initial cost, availability, high operating cost, large land holding, unapproachable areas. Hence a Reaper binder is a good alternative for harvesting crops. Reaper is found 14 times efficient in cutting and placing cereals compared to day labour (Meisner et al., 1997). The main objective of this paper is to study the field performance and cost economics evaluation of reaper - cum - binder for harvesting of wheat.

\section{Materials and Methods}

\section{Site selection}

The field survey and experiment of Reaper binder was done in different villages of Tehsils of Satna district (i.e. Rampur Baghelan, Majhgawan, Amarpatan, Nagod, Uchehara, Maihar, Raghurajnagar,). The SATNA district lies between the north latitude $23^{\circ} 05^{\prime}$ and $25^{\circ} 12^{\prime}$ and eastern latitude $80^{\circ}$ $21^{\prime}$ and $81^{\circ} 23$ 'and $415 \mathrm{~m}$ above MSL.

All the treatments were replicated twice. The size of the experimental plot was 0.4 ha (1 acre). The wheat crop was sown in the fields with the help of seed cum fertilizer drill in the month of November 2016. However the performance evaluation of different types of reaper binder was executed in April 2017.

\section{Climate condition}

Wheat is a Rabi crop generally sown in the month of November and harvested during April. The average normal annual rainfall is 
about $1353.8 \mathrm{~mm}$ which occurs $87.7 \%$ during monsoon period. The remaining months are usually dry, except for light occasional showers.

\section{Selected treatments}

The following four treatments were selected for the experiment:-

$\mathrm{T} 1=$ The $1.22 \mathrm{~m}$ Reaper binder is powered by $10 \mathrm{HP}$ diesel engine. (Italian self-propelled) 3 Wheel (Machine 1)

$\mathrm{T} 2=$ The $1.22 \mathrm{~m}$ Reaper binderpower by PTO of tractor (Italian tractor mounted) (Machine 3)

$\mathrm{T} 3=$ The $1.22 \mathrm{~m}$ Reaper binder is provided by 10 HP diesel engine (Italian self-propelled) 4 Wheel (Machine 2)

\section{T1/T2/T3 - Reaper binder}

Reaper binder is a unique harvesting machine that reaps the crop as well as binds it simultaneously with a twine. This Innovative mechanical machine ensures maximum recovery of straw with negligible grain losses at a surprisingly low cost of operation. This machine is mainly used in Wheat, Paddy, Oats, Barley and other grain crops.

\section{Field survey}

A questionnaire based field survey was conducted in the district. Random samples were drawn for analysing these technologies (i.e. mechanical harvesting using Reaper binder). The farmers were enquired about the technology in all the Tehsils of the Satna district. The details about the owners of the Reaper binder in the district were taken from the Agricultural Engineering workshop, Satna. The study was carried out on sampling basis.
The samples were the representative of the entire Tehsil.

\section{Field experiment}

Field experiment was carried out for the performance evaluation of Reaper binder and for wheat crop at different tehsils of Satna districts selected on the basis of random sampling. The soil texture was identified as loam soil, clay soil and sandy soil whereas the soil type was identified as yellow soil, alluvial soil. The field experiment was carried out during Rabi season. Field capacities (theoretical field capacity and effective/actual field capacity), field efficiency, cost of operation, benefit - cost ratio etc. were studied for mechanical harvesting using Reaper binder.

A plot was selected to determine the operational speed of reaper binder, field capacity (ha/hr), number of labours required for machine harvesting, crop residual management and cost of operation. The area of the plot was measured with the help of tape. The plot was harvested mechanically by using Reaper binder. The Figure 1 shows mechanical harvesting operation using reaper binder.

To calculate the operational speed of the reaper binder, time was recorded taken by the machine to travel a certain distance. The distance was measured with a measuring tape and time was recorded using a stopwatch. Such operations were repeated several times so as to get average speed of operations.

The actual field capacity was be calculated by dividing the total area harvested by total time taken to harvest a certain plot. The theoretical field capacity was calculated by using the formula. The materials or equipment's used for the field experiment are listed in the following table 


\section{Procedure of obtaining machine data}

Forward speed was calculated to measure the theoretical field capacity of the Reaper binder. Total time of field operation was recorded to measure the actual field capacity of the Reaper binderwith turning loss, operator personal loss, machine adjustable loss and troubleshooting loss during field operation. The following formulas were used to measure theoretical field capacity, actual field capacity and field efficiency.

Forward speed was measured by dividing the distance by time required to travel that distance.

Forwardspeed, $s=\frac{d}{t} m / s$

Where, $\mathrm{d}=$ distance travel $(\mathrm{m}), \mathrm{t}=$ time $(\mathrm{s})$

Theoretical field capacity was measured based on the forward speed and the cutting width of Reaper binder.

Theoriticalfieldcapacity, $T F C=\frac{s w}{c} h a / h r$

Where, $s=$ forward speed of travel, $\mathrm{km} / \mathrm{hr}$, $\mathrm{w}=$ total width covered, $\mathrm{m}, \mathrm{c}=$ constant, 10

The actual field capacity is the actual average rate of coverage by the machine, based upon the total field time. The area covered divided by the total time is the actual field capacity.

The actual field capacity was determined from measuring all the time elements involved while harvesting.

Actualfieldcapacity, $A F C=\frac{A}{T} h a / h r$

Where, $\mathrm{A}=$ actual area covered, ha, $\mathrm{T}=$ total time required, $\mathrm{hr}$
The field efficiency was determined by the ratio of actual field capacity (AFC) to the theoretical field capacity (TFC).

Fieldefficiency $(\%)=\frac{A F C}{T F C} \times 100 \%$

\section{Cost calculations}

The input cost of operating Reaper binder was calculated on the basis of fixed cost and variable cost, whereas fixed cost includes depreciation, interest on investment, shelter, taxes and insurance. Depreciation was determined by straight line method as described by Nipa (2016). Variable cost includes fuel, lubricant, repairs and maintenance cost and labour cost.

In this study, repair and maintenance cost was taken as $5 \%$ of the purchase price. The fuel cost (diesel) was considered as Rs. 67.30 per litre while lubricant cost was taken as $30 \%$ of the fuel cost. Useful life of Reaper binder was considered 5 years. The purchase price or capital investment of different Reaper binder were considered Rs.3,30,000, Rs. 4,75,000, Rs.3,00,000.

The machine salvage value was considered as $10 \%$ of purchase price or capital investment. The output cost (i.e. Benefit) was actually determined by obtaining the difference between the manual harvesting operation and mechanical harvesting operation. The labour requirement, break-even point was also determined as described by Alizadeh et. al., (2007) and Nipa (2014).

\section{Input cost}

The input cost of operation of Reaper binderwas determined. The input cost is actually a sum of fixed cost and operating cost. The input cost is generally calculated in per hour basis. 


\section{Fixed cost}

The fixed cost is the cost which is involved irrespective of whether the machine is used or not. These cost include; depreciation cost, interest on investment and taxes, shelter and insurance.

\section{Depreciation}

Depreciation is the reduction in value of a machine with the passage of time. It is the loss of value of a machine with the passing of time. Its formula is as follows:-

$D=\frac{C-S}{L \times H}$

Where,

$\mathrm{D}=$ depreciation per hour (Rs./hr)

$\mathrm{C}=$ capital investment $(\mathrm{Rs}$.

$\mathrm{S}=$ salvage value, $10 \%$ of capital investment

$\mathrm{H}=$ number of working hours per year and

$\mathrm{L}=$ Life of the machine in years

\section{Interest on Investment}

Interest on the investment in a farm machine is a legitimate cost, since money spent in buying a machine cannot be used for other productive enterprises. Interest on investment is calculated on the average investment of the machine taking into consideration the value of the machine in first and last year. The formula of interest on investment is as follows:-

$I=\frac{C+S}{2} \times \frac{i}{H}$

Where, $\mathrm{I}=$ interest on investment per hour (Rs./hr) $i=\%$ rate of interest per hour

\section{Shelter}

Shelter cost is calculated on the basis of the prevailing rates of the locality but roughly speaking, the shelter cost may be taken as $1 \%$ of the initial cost of the machine per year.

It can be mathematically represented as follows

Shelter, $S$

$=1 \%$ of theinitialcostof themachine (i.e.C) (Rs./hr)

\section{Taxes}

Taxes are calculated on the basis of the actual taxes paid per year but roughly speaking, it may be taken as $1 \%$ of the initial cost of the machine per year. It can be mathematically represented as follows

Taxes, $T$

$=1 \%$ of theinitialcosto f themachine (i.e.C) ((Rs./hr)

\section{Insurance}

Insurance charge is taken on the basis of the actual payment to the insurance company but roughly speaking, it may be taken as $1 \%$ of the initial cost of the machine per year.

Insurance, $I$

$=1 \%$ of theinitialcostof themachine (i.e.C) (Rs./hr)

Thus, Total fixed cost is given by the formula

Totalfixedcost $\left(\frac{\text { 目 }}{h r}\right)=D+I+S+T+I$

where the notations have their usual meanings 


\section{Variable cost}

The variable cost of the machine was calculated using the fuel cost, oil cost or lubrication cost, repair and maintenance cost and labour cost (i.e. wages). Sometimes, variable cost is also known as operating cost. The different types of variable cost are further described as follows:

\section{Fuel cost}

Fuel cost is calculated on the basis of actual fuel consumption in the machine. It is generally determined by using the formula as follows

Fuelcost, $F\left(\frac{\text { 圆 }}{h r}\right)$

$=$ Fuelconsumption $\left(\frac{\text { litres }}{h r}\right) \times$ Price $\left(\frac{\text { 圆 }}{\text { litre }}\right)$

\section{Oil cost or cost of lubrication}

Charges for lubricants should be calculated on the actual consumption, but roughly speaking the lubricants cost varies between 30 to $35 \%$ of the fuel cost.

It is generally determined by using the formula as follows:-

Oilcost,$O\left(\frac{\text { 圆 }}{h r}\right)=30 \%$ of fuelcost,$F$

\section{Repair and maintenance cost}

Repairs and maintenance cost was taken 5\% of the initial cost of the machine per year. It is generally determined by using the formula as follows

RepairandMaintenancecost, $R \& M\left(\frac{\text { 专 }}{h r}\right)$ $=5 \%$ of capitalcostperyear, $C$

\section{Labour cost (i.e. wage of labour)}

Labour cost is calculated on the basis of actual wage of the worker. It is generally determined by using the formula as follows:-

Labourcost, $L \frac{\text { 圆 }}{h r}=\frac{\text { Wageoflabour }}{\text { Timeforwhichthelabourishired }}$

For multiple labours the labour cost is multiplied with the number of labours.

Thus, Total variable cost is given by the formula:-

Totalvariablecost $\left(\frac{\text { 圆 }}{h r}\right)=F+O+R \& M+L$

where the notations have their usual meanings.

Thus total input cost is given by the formula as follows

Totalinputcost $\left(\frac{\text { 圆 }}{h r}\right)$
$=$ Totalfixedcost $\left(\frac{\text { 回 }}{h r}\right)+$ Totaloperating cost $\left(\frac{\text { 回 }}{h r}\right)$

\section{Labour requirement}

It may be defined as number of workers and man-hour required for harvesting one hectare of land.

\section{Break-even analysis}

The break-even point, is the area that a machine has to work per year in order to justify the owing the machine. In other words, break-even point (BEP) is that point at which neither profit is made nor loss incurred. It was determined by the following equation (Alizadeh et al., 2007)

Break-even point, $B=\frac{F}{V a-V m}$ 
Where,

$\mathrm{B}=$ Break-even point (ha/year)

$\mathrm{F}=$ Fixed cost of Machine (Rs./year)

$\mathrm{Va}=$ Variable cost for manual method (Rs./ha)

$\mathrm{Vm}=$ Variable cost for machinery method (Rs./ha)

\section{Results and Discussion}

\section{Field performance evaluation}

The field performances of different types of Reaper binder were evaluated. The results drawn from the field performance evaluation of Reaper binder is shown in table 3.1 and its corresponding graph is shown in figure 2 and 3.

\section{Cost calculation}

The cost calculation of different types of Reaper binder were determined on the basis of input cost of operation. The results drawn from the cost calculation of Reaper binder is shown in table 3.2

\section{Labour requirement}

The labour requirement of machine 1, machine 2, machine 3 and machine 4 was found to be 5 man-hr/ha, 5 man-hr/ha, 6.77 man-hr/ha and 2.5 man-hr/ha. Figure 4 shows the labour requirement of different type of reaper binder.

\section{Break - even analysis}

The break-even analysis of machine 1 , machine 2, machine 3 and machine 4 were $32.40 \mathrm{ha} /$ year, $20.47 \mathrm{ha} /$ year, $16.77 \mathrm{ha} /$ year and $15.38 \mathrm{ha} /$ year. Thus it can be concluded that to get benefit from the Reaper binder (i.e. machine 1 , machine 2, machine 3) at least 32.40 ha, 20.47 ha, 16.77 ha needs to be mechanically harvested in a year otherwise its owner may face financial loss. More than 32.40 ha, $20.47,16.77$ ha will provide profit to the machine owner.

The study revealed that the use of reaper binder for harvesting wheat reduced the overall cost of production of wheat. However there were several disadvantages of using the machine for harvesting crops in Satna district such as non-availability of maintenance station as well as spare parts. The cost of maintenance was also found to be high as several parts faces wear and tear while operation. The questionnaire based field survey also revealed that an alternate more brittle and durable material should be substituted so as to increase the working life of reaper binder.

The use of reaper binder is much more economic and efficient for harvesting of crop in Satna district as compared to conventional method. The study was carried out during Rabi harvesting period in 2017 with harvesting of wheat in different tehsils of Satna district selected on random basis.

The field performance was done by using three different machines. Actual field capacity for machine 1, machine 2 and machine 3 were $0.314 \mathrm{ha} / \mathrm{hr}, 0.222 \mathrm{ha} / \mathrm{hr}$ and $0.295 \mathrm{ha} / \mathrm{hr}$ respectively whereas their theoretical field capacity were $0.3623 \mathrm{ha} / \mathrm{hr}, 0.272 \mathrm{ha} / \mathrm{hr}$ and $0.375 \mathrm{ha} / \mathrm{hr}$ respectively. The field efficiency of machine 1 , machine 2 and machine 3 were $86.66 \%, 64 \%, 78.66 \%$, respectively.

The cost economics of different types of Reaper binder was satisfactory which concluded that reaper binder saves a large amount of money in harvesting operations. 
Table.1 List of equipment's used

\begin{tabular}{|c|c|c|}
\hline S.No. & Equipment & Description of use \\
\hline $\mathbf{1 .}$ & Tape & Used for measuring length \\
\hline $\mathbf{2 .}$ & Stop watch & Used to obtain the total time \\
\hline 3. & Data sheet & Used to record the data \\
\hline
\end{tabular}

Table.2 Field performance of different types of reaper binder

\begin{tabular}{|c|c|c|c|c|}
\hline \multirow{2}{*}{ S.No. } & Parameter & \multicolumn{3}{|c|}{ Average value } \\
\cline { 3 - 5 } & & Machine 1 & Machine 2 & Machine 3 \\
\hline 1. & Forward speed, km/hr & 2.97 & 2.14 & 3.073 \\
\hline 2. & Theoretical field capacity, ha/hr & 0.3623 & 0.272 & 0.375 \\
\hline 3. & Actual field capacity, ha/hr & 0.314 & 0.222 & 0.295 \\
\hline 4. & Field efficiency, \% & 86.66 & 81.6 & 78.66 \\
\hline 5. & Labour requirement ,man-hr/ha & 5 & 6.77 & 5 \\
\hline
\end{tabular}

Table.3 Cost calculation of Machine 1, Machine 2 and Machine 3

\begin{tabular}{|c|c|c|c|c|}
\hline \multirow{2}{*}{ S.No. } & Parameter & \multicolumn{3}{|c|}{ Average value } \\
\cline { 3 - 5 } & & Machine 1 & Machine 2 & Machine 3 \\
\hline 1. & Input cost, Rs. per 0.4 ha & 1008.30 & 1596.06 & 1972.94 \\
\hline 2. & Output cost, Rs. per 0.4 ha & 1241.7 & 1643.94 & 1784.845 \\
\hline 4. & Benefit - cost ratio (BCR) & 1.23 & 1.031 & 0.90 \\
\hline 5. & Benefit - cost ratio (BCR)** & 1.09 & 1.037 & 1.02 \\
\hline
\end{tabular}

* When farmer was found the owner of the machine

* When farmer hired the machine on rental basis (Custom hiring)

Fig.1 Mechanical harvesting operation using reaper binder

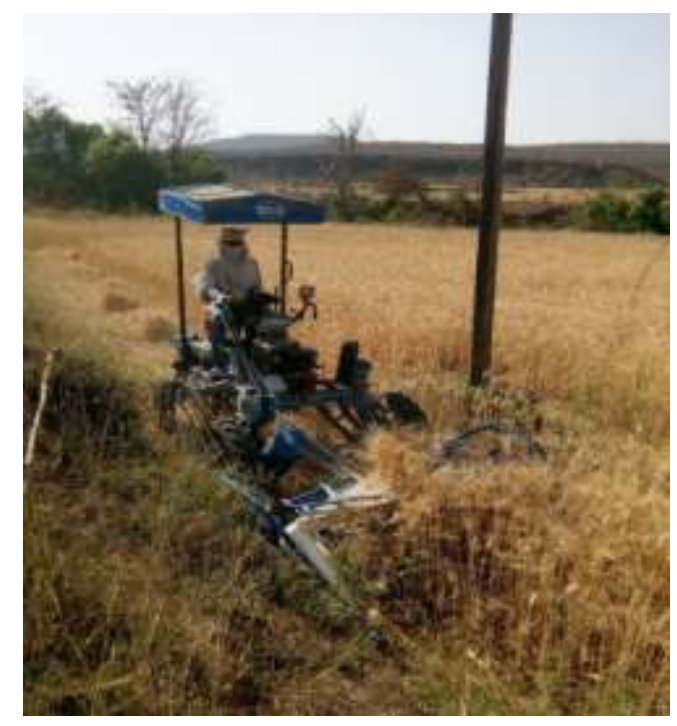


Fig.2 Performance evaluation of different types of Reaper binder

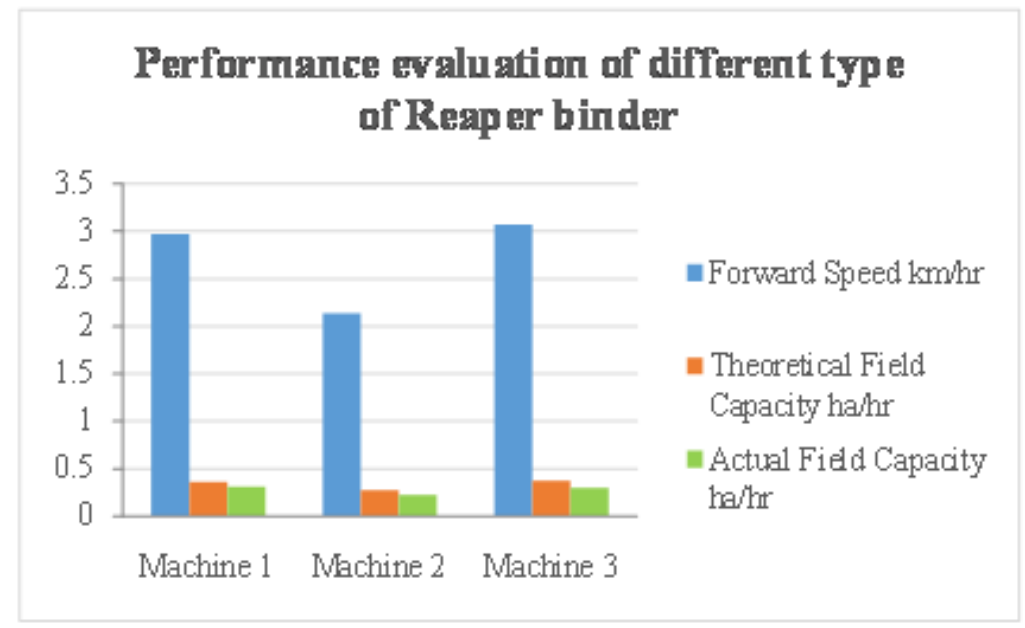

Fig.3 Field efficiency of different types of Reaper binder

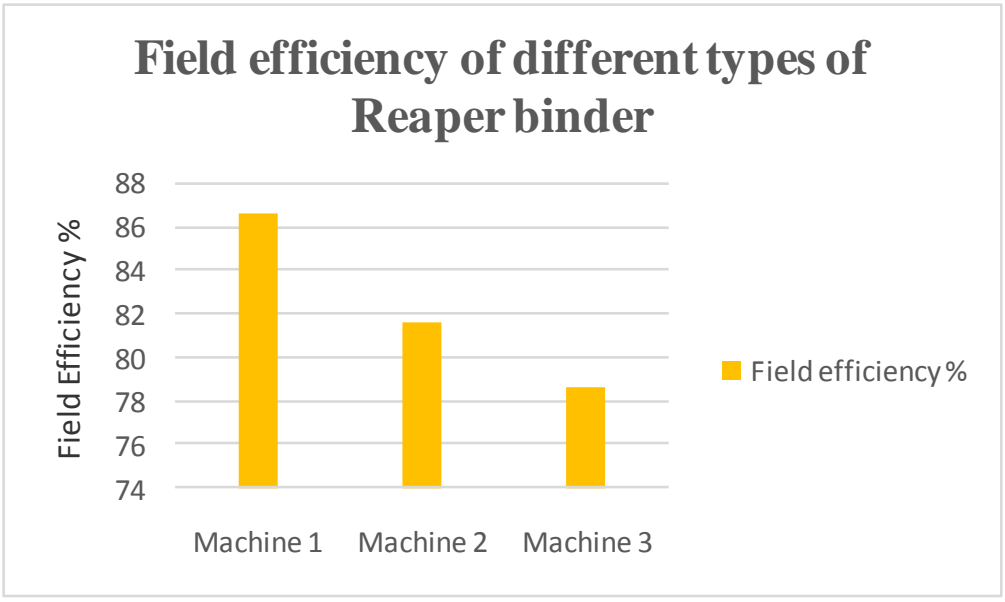

Fig.4 Labour requirement of different type of Reaper binder

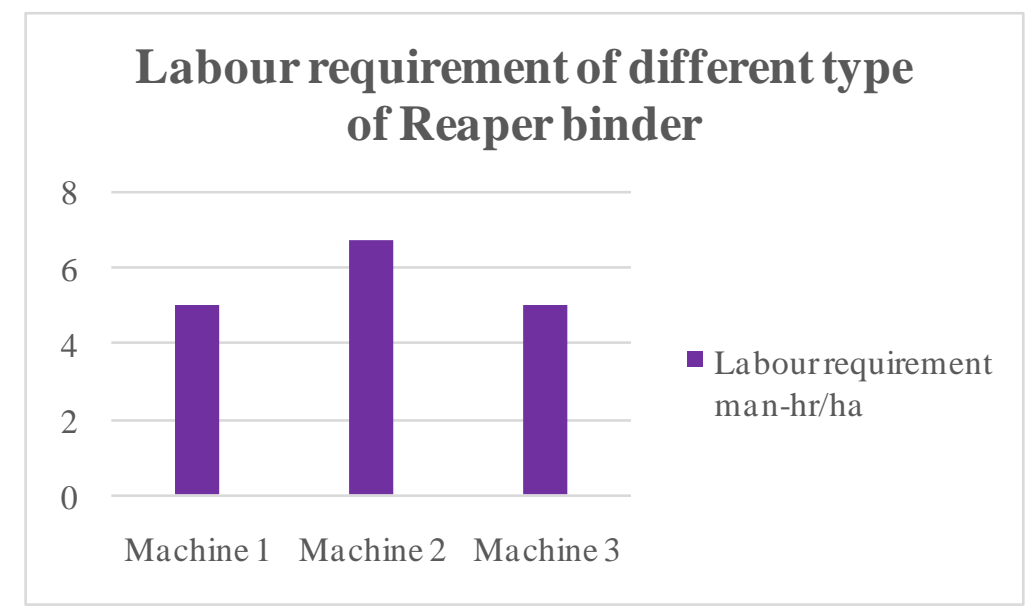


Analysis of cost economics also gave us an idea that different types of reaper binder is beneficial for mechanical harvesting operation using reaper binder except machine 3 (i.e. Italian tractor mounted reaper binder) as its BCR (Benefit - cost ratio) was less than 1 as calculated when the famer is the owner of the machine. All the cost economics were calculated on hiring basis as well as on owing basis.

The labour requirement was also not so high for all the machines used in the study. The break-even analysis of machine 1 , machine 2 and machine 3were 32.40 ha/year, 20.47 ha/year and 16.77 ha/year. Thus it can be concluded that to get benefit from the Reaper binder (i.e. machine 1, machine 2, machine 3) at least 32.40 ha, 20.47 ha, 16.77 ha needs to be mechanically harvested in a year otherwise its owner may face loss. More than 32.40 ha, 20.47, 16.77 ha will increase more profit in a year.

The field survey based questionnaire also revealed that both Reaper binder. Although there were problems of wear and tear in Reaper binder operation it is beneficial for farmers of all types (i.e. small, marginal and large land holding).

\section{References}

Alizadeh. M. R. and A. Allameh (2013) Evaluating rice losses in various harvesting practices. International Research Journal of Applied and Basic Sciences. Volume 4. Issue 4: PP $388-$ 397
Byszewski, W., Haman J. Gleba, maszyna, roslina. Panstwowe

(1977), Wydawnictwo Nauk--owe, Warszawa.

Meisner, C. A., Petter, H., Badruddin, M., Razzaque, M. A., Giri, G. S., \& Scott, J. (1997). Mechanical revolution among small landholders of South Asia: The growing use of Chinese hand tractors. In Proc. of the Joint Intl. Conf. on Agril. Eng. \& Tech. Exhibition '97, Dhaka (Vol. 3, pp. 781-787).

Mondol, M. R. A. (1997). Performance evaluation and improvement of power tiller mounted cereal reaper (Doctoral dissertation, MS thesis).

Nadeem A., and Gee-Clough, D. (1983). Field performance evaluation of rice reaper. AMA, agricultural mechanization in Asia, Africa and Latin America.

Nipa, J. F. (2016, March). Study on performance evaluation of selfpropelled reaper. In Proceedings of the International Conference on Industrial Engineering and Operations Management, Kuala Lumpur, Malaysia.

Pandey, M. M., and Devnani, R. S. (1985). Design, development and field evaluation of Vertical Conveyor Reaper Windrower. Agricultural Mechanization in Asia, Africa and Latin America, 16(2), 41-52.

Shakoor, A. K., and M. Salim (2005), Rice harvesting and threshing. Pakistan Journal of Food Science, 15(1-2): PP 45

52.

\section{How to cite this article:}

Himanshu Rao, J. and Balveer Singh Meena 2019. Performance and Cost Economics Evaluation of Different Types of Reaper Binder for Harvesting of Wheat in Satna District of Madhya Pradesh, India. Int.J.Curr.Microbiol.App.Sci. 8(10): 2115-2124. doi: https://doi.org/10.20546/ijcmas.2019.810.246 